\title{
The Economic and Environmental Impact of a Carbon Tax for Scotland:
}

\section{A Computable General Equilibrium Analysis*}

\author{
Grant Allan ${ }^{\mathrm{a}, \mathrm{b}, \mathrm{c}}$, Patrizio Lecca ${ }^{\mathrm{a}, \mathrm{b}, \mathrm{c}, \mathrm{d}^{*}}$, Peter McGregor ${ }^{\mathrm{a}, \mathrm{b}, \mathrm{d}}$ and Kim Swales $\mathrm{s}^{\mathrm{a}, \mathrm{b}, \mathrm{c}, \mathrm{d}}$
}

a. Department of Economics, University of Strathclyde, United Kingdom.

b. Strathclyde International Public Policy Institute

c. Fraser of Allander Institute, University of Strathclyde, United Kingdom

d. Centre for Constitutional Change

* Corresponding author: Department of Economics, University of Strathclyde, Rm. 6.15, Sir William Duncan Building 130 Rottenrow, Glasgow G4 OGE. Tel: +44(0) 1415483962 Email:patrizio.lecca@strath.ac.uk.

Acknowledgements. The research reported here was supported by ClimateXChange, the Scottish Government-funded Centre of Expertise in Climate Change and the ESRC's Future of Scotland pre and post referendum Initiative. The views expressed are the sole responsibility of the authors, not necessarily those of ClimateXChange, the Scottish Government or ESRC. The authors gratefully acknowledge assistance from Marie Tamba and Matthew Winning and the helpful comments of two anonymous referees. 


\title{
The Economic and Environmental Impact of a Carbon Tax for Scotland: A Computable General Equilibrium Analysis*
}

\begin{abstract}
Using a disaggregated energy-economy-environmental model, we investigate the economic and environmental impact of a Scottish specific carbon tax under three alternative assumptions about the use of the revenue raised by the tax: revenues raised are not recycled within Scotland; revenues are used to increase general government expenditure or to reduce Scottish income tax. We find that by imposing a tax of $£ 50$ per ton of $\mathrm{CO} 2$ the $37 \% \mathrm{CO} 2$ reduction target is met with a very rapid adjustment in all three cases if the model incorporates forward-looking behavior. However, the adjustment is much slower if agents are myopic. In addition, the results of the model suggest that a carbon tax might simultaneously stimulate economic activity while reducing emissions and thus secure a double dividend, but only for the case in which the revenue is recycled through income tax.
\end{abstract}

Keywords: Carbon Tax, CGE Modelling, Double Dividend, Regional Economics

JEL: C68, Q51, Q58 


\section{Introduction}

Since devolution, the Scottish Government has increasingly adopted a distinctive environmental and energy policy (Allan et al., 2008). The Climate Change (Scotland) Act includes a target to reduce $\mathrm{CO}_{2}$ emissions to $42 \%$ below 1990 levels by 2020. This is stricter than the $34 \% \mathrm{CO}_{2}$ emissions reduction adopted by the UK Government. Moreover, the corresponding Scottish Government target for renewable electricity generation in 2020 is equivalent to $100 \%$ of electricity consumption in Scotland and preliminary data suggest that the interim 2011 target of $31 \%$ was exceeded by 4 percentage points.

However, earlier discussions have established that whilst Scotland has adopted challenging targets, many key policy instruments are reserved to the UK government (Allan et al., 2008; McGregor et al., 2011). At present the main "green" elements of the tax system remain under Westminster control. This includes fuel duties, air passenger duty and the climate change levy. Also reserved to the UK Government are: the tax-transfer system; powers over the structure and regulation of the electricity market; Renewable Obligations Certificates, the Renewable Transport Fuels Obligation and the Renewable Heat Incentive; Climate Change Agreements; and the Carbon Reduction Commitment.

The Scottish Government has succeeded in making Scottish energy policy more distinctive, first through setting different targets (as described above) and second by developing specific policies within the non-reserved powers at their discretion. These powers include the judicious use of the planning system and additional funding for alternative renewable technologies in pre-commercial scales, such as the Wave and Tidal Energy Scheme (WATES), The Saltire Prize, and the Scottish Community and Households Renewables Initiative. Nevertheless, the Committee on Climate Change 
report into Scottish emissions targets concluded that with current policies, and assuming the current cap on emissions under the EU ETS, the Scottish Government's target of a $42 \%$ reduction will be missed, with emissions only falling by $38 \%$ on 1990 levels.

Economists typically regard a carbon tax as the most efficient way to reduce carbon emissions (Tullock, 1967; Pearce, 1991). Furthermore, continuing pressure for greater fiscal autonomy is likely to expand the range of climate change policies that the Scottish Government has at its disposal (McGregor and Swales, 2013). It is therefore of interest to consider the effect of a Scottish specific carbon tax. This is particularly relevant given the more demanding environmental targets set by the Scottish Government and the present discussions around increased fiscal autonomy for Scotland. The Scotland Act (2012) has augmented the income tax raising power of the Scottish Parliament, so that it will have the power to make a balanced-budget adjustment in public expenditure funded by corresponding changes in the basic as well as higher rates of income tax of up to 10p in the pound ${ }^{1}$.

In this paper we employ an empirical energy-economy-environmental model ${ }^{2}$ of Scotland to simulate the impact of a Scottish specific carbon tax on the levels of carbon emissions and of aggregate and sectoral economic activity. The simulations are conducted under alternative assumptions about the use of the revenues raised by the tax, for example, to increase general Government expenditure or to reduce the rate of income tax.

\footnotetext{
${ }^{1}$ Originally the Scottish Parliament had the authority to change only the basic rate of income tax up to $3 p$ in the pound.

${ }^{2}$ Several works analyses the macroeconomic impact of introducing a carbon tax using macroeconomic modeling: See e.g., Symons et al (1994) for UK, Wissema and Delling (2007), for Ireland, Bovenberg and Goulder, (1996) and Goulder, (1995) for US and Cornwall and Creedy (1996) and Adams and Parameter (2013) for Australia.
} 
The remainder of the paper is organised as follows. Section 2 outlines the arguments for a carbon tax and introduces the notion of the double dividend. Section 3 summarises the key features of the model. Section 4 briefly describes the model parameterization and discusses the simulation set up. Section 5 discusses the simulation results. In Section 6 we provide a sensitivity analysis and in Section 7 we present brief conclusions.

\section{The case for a carbon tax}

Firms, households and governments generate emissions of $\mathrm{CO}_{2}$ that impose a cost on present and future generations in the form of global climate change. ${ }^{3}$ However, those directly emitting $\mathrm{CO}_{2}$ do not directly bear the cost of their own emissions. That is to say, they are not forced specifically to take these costs into account when they make production and consumption decisions. These costs are known generically as externalities and the notion that they can be internalised by the governments' setting a tax equal to the marginal cost imposed on others was first suggested by Pigou (1920). Coase (1960) persuasively argues that imposing appropriate property rights can also solve this problem. In this case, the owners of the right to pollute the atmosphere would charge for allowing individuals and organisations to emit $\mathrm{CO}_{2}$. This is the basis for the use of tradable permits for controlling emissions ${ }^{4}$. However, the fundamental principle behind carbon taxes and carbon trading is the same $e^{5}$. A price

\footnotetext{
${ }^{3}$ We do not question the science here. For a robust rebuttal of the climate change sceptics, see Nordhaus (2012).

${ }^{4}$ Adams and Parmenter (2013) using a single-country multiregional CGE model of Australia interfaced with a multicountry global economic model such as GTEM (Pant, 2007) evaluate the impact of a global emissions trading scheme.

${ }^{5}$ Weitzman (1974) discusses the cases where these approaches differ under uncertainty.
} 
should be set for emitting carbon, either through a specific tax or the requirement to acquire a permit.

Essentially, the arguments that favour treating externalities in this way, are similar to those that favour the use of free markets in general. It is an effective means of decentralised decision making. In this specific case, the government has set targets for the level of carbon emissions. However, this decentralised approach should lead to these targets being met at minimum cost in terms of consumption foregone. Setting a price on carbon emissions generates an appropriate set of incentives. For instance, firms will seek to adopt less emissions-intensive production techniques. Given that the price of products that embody carbon emissions will rise, consumers will tend to consume less of these products. Further there is an increased incentive for technical change that involves reducing carbon emissions in the future (Goulder and Schneider, 1999; Goulder and Mathai, 2000).

There is an additional potential benefit from the use of carbon taxes. Carbon taxes (or tradeable permits, if owned by the state) are sources of revenue for the government ${ }^{6}$. This additional revenue can be used to reduce other taxes that generate distortions in the operation of the economy, thereby producing a so-called 'double dividend'. Here, not only are $\mathrm{CO}_{2}$ emissions reduced (the first dividend), but the efficiency with which other elements of the economy operate can be simultaneously improved (the second dividend) generating a decrease in the unemployment rate, increase in employment rate and in GDP. In the literature, there is extensive discussion concerning

\footnotetext{
${ }^{6}$ A key role of the government is to produce public goods: goods that provide freely available services where it is difficult to exclude individuals from benefiting from these services. These goods are provided inadequately by the private market. The classic example is defence.
} 
the possible nature of this second dividend and the circumstances under which it exists ${ }^{7}$. Using applied general equilibrium models, Bor and Huang (2010), Bovenberg and Van der Ploeg (1998), Glomm et al. (2008), Goulder (1995), Manresa and Sancho (2005), Hoel and Schneider (1997), all find evidence of the existence of the second dividend and in some cases even a triple dividend, which is associated with a decrease in poverty (Van Heerden et al. 2006).

\section{The AMOSENVI model of Scotland}

\subsection{General model features}

AMOSENVI is a large scale, multi-sectoral energy-economy-environment computable general equilibrium model for Scotland. The model has seventeen industry sectors ${ }^{8}$ of which thirteen are energy sectors. Among energy sectors we identify nine electricity generation sectors. Production inputs include primary factors (labour and capital) and intermediate purchases. The model includes three domestic institutional sectors: Firms, Households and Government.

External institutions are split into the Rest of UK (RUK) and Rest of the World (ROW). We adopt assumptions typically used for a small open economy. In particular the region is too small to affect prices in international and interregional markets so that the RUK and ROW prices are taken to be exogenous ${ }^{9}$.

\footnotetext{
${ }^{7}$ See Goulder (1995), Bovenberg and Goulder (1996), Fullerton and Metcalf (1998) for a clear account of the issues and Bosquet (2000) for a survey of the double dividend literature on environmental taxes.

${ }^{8}$ See Table A1 in the Appendix for details about sectoral aggregation.

${ }^{9}$ AMOSENVI is a single country model where the RUK and the ROW are exogenous in the model therefore we are not able to capture the spillover coming from the RUK or the ROW. This seems is a reasonable first approximation given that the Scottish economy is less than $9 \%$ of the UK economy on any measure of scale.
} 
The model can be solved with either myopic or forward-looking expectations. In the former case agents have adaptive expectations so that they abstract from future periods, while in the latter case firms and consumers have perfect foresight and react to anticipated future events. Except where explicitly stated the model is run here under perfect foresight.

\subsection{Production structure}

Production is characterized by cost minimization with standard, well-behaved production functions. The production structure of the model is represented by a multi-level constant elasticity of substitution (CES) production function as is illustrated in Figures 1 and 2. Figure 1 shows the structure of the Electricity supply sector while Figure 2 is a schematic of the structure of production for all the other sectors of the economy.

For all sectors, value added and intermediate inputs combine to produce total gross output. Value added is obtained by combining capital and labour. Intermediate inputs are decomposed into energy and non-energy inputs. Then energy is split in Electricity and non-Electricity. The latter is divided between Oil and Non-Oil then Non-Oil is further disaggregated between Gas and Coal.

In the electricity sector we distinguish between Transmission and Generation, where the latter is in turn a combination of intermittent and non-intermittent electricity generation. The intermittent sectors are Marine and on- and off-shore Wind Generation. The non-intermittent composite is further split between Low Carbon and High Carbon electricity generation.

Intermediate inputs (both energy and material) can be purchased locally or imported from the Rest of UK (RUK) and from the Rest of the World (ROW). Regional and imported goods are combined 
through a CES function. This means that intermediate goods produced locally or imported are considered as imperfect substitutes (Armington, 1960). The demand function for regionally produced and imported intermediate inputs derives from the solution of a cost minimization problem.

Each industry in the region produces goods and services that can be exported or sold in the regional market. An export demand function closes the model where the foreign demand for Scottish goods and services depends on the terms of trade effect and on the export price elasticity.

\subsection{Consumers}

The infinitely lived consumer chooses a sequence of consumption that maximizes the present value of utility, as summarized by the lifetime utility function which takes the following form:

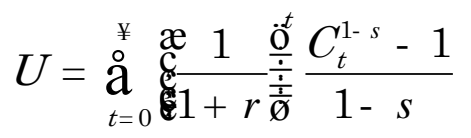

where $C_{t}$ is the consumption at time period $t, S$ and $r$ are respectively the constant elasticity of marginal utility and the constant rate of time preference. The dynamic budget constraint ensures that the discounted present value of consumption must not exceed total household wealth. Once the optimal path of consumption is obtained from the solution of the intertemporal problem, the aggregate consumption is allocated intra-temporally between commodities through a CES function. Household demand for regional and imported goods is the result of the intra-temporal cost minimization problem and, similarly to the production side, domestic and imported commodities are imperfect substitutes.

\subsection{Investment}


We model the investment decision as in Hayashy (1982) where the rate of investment is a function of marginal $q$ (or average $q)^{10}$ which is the ratio of the value of firms $(V F)$ to the replacement cost of capital $(P k \cdot K)$. Thus, the path of investment is obtained by maximizing the present value of the firm's cash flow given by profit, $p_{t}$, less private investment expenditure, $I_{t}$ subject to the presence of adjustment cost $g\left(x_{t}\right)$ where $x_{t}=I_{t} / K_{t}$ :

$$
\operatorname{Max} \sum_{t=0}^{\infty} \frac{1}{(1+r)^{t}}\left[\pi_{t}-I_{t}\left(1+g\left(x_{t}\right)\right)\right] \quad \text { subject to } \dot{K}_{t}=I_{t}-\delta K_{t}
$$

The solution of the dynamic problem gives us the law of motion of the shadow price of capital, $\lambda_{t}$ and the time path of investment related to the tax-adjusted Tobin's $q$ (Tobin, 1969).

Investment by sector of destination are transformed to investment by sector of origin through a capital matrix constructed using a simple cross entropy estimation. Capital goods can be purchased locally or imported. Imperfect substitution between locally and imported capital goods is introduced through a CES function.

\subsection{Labour market and migration}

The labour market is characterized by imperfect competition. Thus the wage rate is determined through a wage bargaining function or wage curve (Blanchflower and Oswald, 1994) according to which real wages and unemployment are negatively related:

\footnotetext{
${ }^{10}$ As we are assuming that the firm is price taker, marginal $q$ is equal to average $q$. For further details see Hayashy (1982).
} 


$$
\ln \left(\frac{w_{t}}{c p i_{t}}\right)=c-0.113 \cdot \ln \left(u_{t}\right)
$$

where: $c$ is a calibrated parameter, $w$ is the nominal wage, $u$ is the unemployment rate and $c p i$ is the consumer price index. The wage-unemployment elasticity is -0.113 (Layard et al., 1991).

There is no change in natural population; however the labour force $(L S)$ evolves over time through migration:

$$
L S_{t}=L S_{t-1}\left(1+m_{t}\right)
$$

where $m$ is net in-migration as a proportion of the regional population. In each period, migration is positively related to the gap between the log of regional and national $\left(w^{N} / c i^{N}\right)$ real wages, and negatively related to the gap between the $\log$ of national, $\left(u^{N}\right)$ and regional unemployment rates $u$ where $u^{N}, w^{N}$ and $c p i^{N}$ are are not time-varying:

$$
m_{t}=\varsigma-0.08\left[\ln \left(u_{t}\right)-\ln \left(u^{N}\right)\right]+0.06\left[\ln \left(\frac{w_{t}}{c p i_{t}}\right)-\ln \left(\frac{w^{N}}{c p i^{N}}\right)\right]
$$

Where $\varsigma$ is a parameter calibrated in order to ensure zero net migration in the base year. In equation (5) regional population adjusts according to the econometrically parameterised regional net migration function reported in Layard et al. (1991). The elasticities incorporated are -0.08 for the gap between the regional and national unemployment rate and 0.06 for the gap between the regional and national real wages.

\subsection{Government}


Government expenditure comprises current spending on goods and services and transfers to households and firms. Its revenues are given by labour and capital income taxes, indirect taxes on production and an ad valorem tax on the use of fuels. When a balanced budget is applied either government consumption or the income tax rate are endogenous.

\subsection{Equilibrium}

The total absorption equation provides equilibrium in the commodity market. This is sufficient to guarantee equilibrium in the payments account since we are not considering money as a commodity.

As for the capital market, capital demand equals the capital stock. In general, the labour market is equilibrated through endogenous changes in wage and unemployment rates.

\subsection{Myopic specification}

The myopic model developed here is similar in structure to the model described above. The differences are in consumption and investment. In each period, consumption is a linear function of real disposable income. Thus, contrary to the perfect foresight case, myopic consumers preserve the condition of stability between current consumption and wealth during the entire transitional path.

As for investment, the adjustment rule introduced in the myopic model is consistent with the neoclassical formulation developed in Jorgenson (1963): investments are determined as a fraction of the gap between the desired and actual level of capital stocks adjusted for depreciation. This is also wholly compatible with the Uzawa (1969) formulation of adjustment costs where the investment capital ratio is determined by the rate of return to capital and the user cost of capital, allowing the capital stock to reach its desire level in a smooth fashion over time. 


\section{Dataset, parameterization and simulation strategy}

\subsection{Database and parameterization}

The model is calibrated using a Scottish Social Accounting Matrix (SAM) for the year $2000^{11} \cdot \mathrm{CO}_{2}$ emissions for Scotland are reported in Table A2 in the Appendix. Emissions data together with the data on energy volume and related sectoral CO2 intensities are estimated in Turner (2002).

Some of the elasticities of substitution and other behavioural parameters are based on econometric estimation or best guesses. For all sectors, trade elasticities are set equal to 2 (Gibson, 1990) whilst elasticities between labour and capital is equal to 0.3 (Harris, 1989). Between energy and nonenergy, electricity and non-electricity and between Oil and non-oil the elasticity is equal to 2; between transmission and generation the elasticity is set to 0.3 . For all renewable electricity the elasticity of substitution equals 5 .

The interest rate (faced by producers, consumers and investors) is set to 0.04 , the rate of depreciation to 0.15 and the constant elasticity of marginal utility equals to 1.2 (Evans, 2005).

\subsection{Simulation set up}

The simulations impose a tax on carbon emissions generated in production. This is achieved by introducing an ad valorem tax on the use of the three domestic and imported fossil fuel energy sources - coal, oil and gas - in their use as intermediate inputs in the production of other Scottish goods and

\footnotetext{
${ }^{11}$ The model is calibrated using a relatively old database. However, given the level of aggregation across nonenergy sectors, it is reasonable to assume that the structure of the Scottish economy has remained comparatively stable.
} 
services. The actual tax rate imposed is differentiated according to the carbon content of each fuel. The tax is imposed in the first period and maintained at a constant rate. The model is run forward with no other changes until a new steady-state equilibrium is attained.

The tax generates revenue for the public sector. We run three simulations that differ in the way in which these funds are recycled. In one simulation the revenues revert to the UK Government and are spent outwith Scotland. ${ }^{12}$ In the other two simulations, the funds are used in Scotland. In one the revenues are recycled through an expansion in general government expenditure. In the other the revenues are used to reduce income tax.

The Scottish Government's target is to reduce $\mathrm{CO}_{2}$ emissions by $42 \%$ in 2020 , compared to the total in 1990. Our model is calibrated for the year 2000. Because there had already been some reduction in emissions in the decade leading up to 2000, to achieve the Scottish target requires a $37 \%$ reduction of $\mathrm{CO}_{2}$ emissions in the 20 years to 2020. By trial and error, simulation indicates that the target can be met by a carbon tax of $£ 50$ per tons of $\mathrm{CO}_{2}$. This can be seen in Figure 3 where we plot, for a range of possible tax rates, the associated reduction in total $\mathrm{CO}_{2}$ emissions. On the vertical axis we show the carbon tax rate in pounds per ton while on the horizontal axis we plot the 2020 percentage reduction from base year values in total $\mathrm{CO} 2$ emissions. The relationship between tax rate and $\mathrm{CO} 2$ reduction is shown for the two methods of recycling revenues within Scotland and for the external recycling case.

\footnotetext{
${ }^{12}$ It is not clear why a devolved Scottish Government would agree to such an arrangement, since this implies a Scottishspecific fiscal contraction. The arrangement would be much more likely to apply in the case of a UK wide carbon tax imposed by Westminster. The case provides a useful benchmark, in which the revenues raised are not recycled at all within Scotland.
} 
By imposing a tax of $£ 50$ per ton of $\mathrm{CO}_{2}$, the total tax-take corresponds, in our base year, to $£ 1662$ million at 2000 prices.

\section{Simulation Results}

\subsection{Economic impact}

Table 1 reports results for key economic variables for the three variations on the use of tax revenues. Results are expressed in terms of percentage changes from initial steady state equilibria and are presented for both the short- and long-runs. The short-run results give the impact in period one, during which both capital stocks and population are fixed at their base-year values. The long-run results apply when all capital stocks and the population have fully adjusted to the disturbance.

In all three cases the introduction of the carbon tax leads to a substantial reduction in $\mathrm{CO}_{2}$ emissions. The $37 \% \mathrm{CO}_{2}$ reduction target is met with a very rapid adjustment even in the first period. However, the impacts on the aggregate activity variables, GDP and total employment, are much smaller in the short run and their sign depends on how the tax revenues are recycled. In other CGE applications (see e.g. Bovenberg and Goulder, 1996) the first dividend is always easily met, regardless of the way in which the revenue is recycled. However, the impact on welfare and economic activity can change dramatically with the chosen method of recycling the additional revenue.

Where the tax revenue is externally recycled the carbon tax clearly has a depressing effect on the Scottish economy. The cost of fossil fuels used in production increases thereby reducing the industrial demand for fuels. This generates an overall contractionary impact on production and final demand. GDP decreases by $0.30 \%$ in the short run and $2.68 \%$ in the long run. Employment initially falls by 
more than GDP, as labour is more flexible than capital in the short run. Indeed, labour is mobile across sectors from the outset. The fall in labour demand causes a rise in the unemployment rate of $4.1 \%$ in the short-run. However, the impact of outmigration, triggered by the adverse local labour market conditions, causes the unemployment and real wage rate return to their original levels in the long-run. In the long-run the labour force falls by $2.60 \%$, just less than the fall in GDP. This also means that in the short-run the capital/labour ratio rises due to the absence of migration whereas after complete adjustment the capital/labour ratio falls.

In the long run nominal wages increase by $0.81 \%$ from base year value as workers attempt to maintain their real wages. The replacement cost of capital rises by $0.63 \%$ depressing investment and thus capital stocks, which fall by $2.82 \%$. The increase in prices produces negative competitiveness effects reducing exports by $1.23 \%$.

For the case where revenues are recycled through increased Government expenditure, the negative impact of a decrease in the use of energy is accompanied by a counterbalancing effect generated by the increase in Government expenditure. This latter effect operates as a demand side stimulus. The simulation results show a significant reduction in $\mathrm{CO}_{2}$ emissions, and a net effect on aggregate economic activity that is again contractionary.

In this simulation there is an increase in public expenditure of $4.66 \%$ in the short-run and $3.97 \%$ in the long-run, funded by the additional carbon tax revenues. GDP, employment, capital stock and consumption fall in both time frames. The fall in activity is however less than the externally recycled scenario. The increase in public spending is only able partially to mitigate the adverse supply side 
effects of the tax. The long-run effects on prices are the same as the externally recycled scenario (see e.g. wage and the replacement cost of capital in Table 1). This is what we would expect if the production factors are allowed to adjust fully in the long run given that the increase in government expenditure has only demand side effects ${ }^{13}$.

In the model presented here we abstract from the potential supply-side effects that may arise from the increase in public expenditure (see e.g. Lecca et al., 2010, 2012). A different outcome would be possible if the increase in public expenditure was allocated to public investment, rather than current expenditure, which in turn would increase the stock of the public capital. Furthermore, we are not capturing any possible amenity effects of the increased government expenditure on the individual's decision to migrate. In the present application the potential migrant is indifferent between marginal changes in local public expenditure and private consumption. However, different results can arise if there is a positive marginal preference for local public expenditure (Lecca et al, 2010, 2012).

A qualitatively different outcome for economy activity is obtained where the carbon tax revenues are used to reduce the average rate of personal income tax. The results shown in Table 1 indicate that, under the circumstances assumed in this simulation, the implementation of such a revenue-neutral set of tax changes not only reduces $\mathrm{CO} 2$ emissions, but also stimulates economic activity and jobs. In this case revenue recycling reduces the rate of income tax, which falls in both the short and the long run by $6.16 \%$ and $5.37 \%$ respectively. This would be within the range of income tax variation proposed in the Scotland Act (2012) which provides the Scottish Parliament with greater tax raising powers.

\footnotetext{
${ }^{13}$ This would not be the case with fixed labour supply or with limited labour mobility.
} 
The net impact on the Scottish economy is positive, resulting in an increase in GDP of $0.26 \%$ and $0.83 \%$ in the short and long-run respectively. Employment and household consumption increase in both time periods.

The short-run expansion in economic activity increases the demand for labour thereby reducing the unemployment rate in the short run by $3.77 \%$ from base year values and so increasing the real wage after tax by $0.43 \%$. The increase in the real wage stimulates household consumption which increases by $1.18 \%$ from base year values. In the short-run commodity prices have increased generating some crowding out of exports, which fall by $0.29 \%$.

The combined effect of a rise in the real wage after tax and the reduction in unemployment rate encourage in-migration. Simultaneously, in-migration puts downward pressure on the real wage during the transition path. The resulting in-migration increases labour supply, again pulling the real wage and the unemployment rate back to their base year value in the long-run The long run fall in nominal wages is accompanied by an increase in labour supply and competitiveness with increased household consumption (1.45\%) and exports (0.05\%) drive the expansion in the economy.

Furthermore, the increase in private capital stock puts downward pressure on the capital rental rate, producing a system wide efficiency stimulus lowering commodity prices, which in turn push the replacement cost of capital below its base year value. The real shadow price of capital increases, so that Tobin's q moves procyclically, ultimately encouraging additional investment and so capital stocks. 
Employment increases by $0.42 \%$ in the short run and $1.06 \%$ in the long run. In this scenario the percentage change in employment is greater than the percentage change in GDP in both time frames shown here.

In Figure 4 we report the short and the long-run changes in sectoral output where the revenue is recycled through reduced income taxes. Of course, the introduction of the carbon tax directly increases the price of coal, oil and gas when these are used as an input in production, so that the demand for these fuels falls, reducing dramatically their production and import levels. Electricity supply increases in the short run, as a result of the small increase in economic activity. However, in the long run, when there has been a full adjustment to the new prices, electricity supply falls. There is, however, a significant increase in electricity generated from renewable energy. The share of electricity generated by renewables as a share of electricity consumption in Scotland increases in the long run by slightly less than $20 \%$, reflecting also the large fall in output in the coal and gas electricity generation sectors. As for the non-energy sectors, only the primary sector shows a long-run reduction in output.

\subsection{The impact on $\mathrm{CO}_{2}$ emissions}

In Figure 5, we show the period-by-period reduction in $\mathrm{CO}_{2}$ emissions from the base period. Note that for all three simulations the carbon tax is able to achieve the $37 \%$ target emissions reduction by the year 2020. This target is met after only 5 years when the revenue is either externally recycled or

used to increase public expenditure within Scotland. With revenue recycling through a reduction in personal income tax, the target is achieved after ten years. 
All the simulations reported up to now have incorporated forward-looking behavior on the part of all agents. In Figure 6 we compare the period-by-period impact of the carbon tax on the level of $\mathrm{CO}_{2}$ emissions under both forward looking and myopic assumptions. Again we report the percentage change from base year values of total $\mathrm{CO}_{2}$ emissions for the simulations where the carbon tax revenue is used to reduce income tax. As we would intuitively expect, both the myopic and forward-looking model reach the same long-run equilibrium, regardless of agents' expectation formation process. (Lecca et al, 2013). However, whilst with perfect foresight the target is achieved in less than ten years, with the myopic model we are only able to reach the target by 2025.

This has implications for the need for credibility in the implementation of the environmental policy by the Scottish Government. In order that agents can optimally adjust to policy by anticipating its future effects, those agents must believe that the policy will be maintained in the future. In the myopic case, the agents have adaptive expectations. They adjust only with respect to present prices and outputs. The adjustment is much slower if transactors do not believe the Government's commitment to the tax change and form their expectations accordingly.

In Figure 7 we show the short-run and long-run change in $\mathrm{CO}_{2}$ emissions at the sectoral level. Note that there are huge reductions in emissions in all energy sectors. In the long run, emissions in the coal and the coal electricity generation sectors fall by $70 \%$ and $79 \%$ respectively. As for the non-energy sectors, the biggest reduction in emissions are in the manufacturing and the service sectors, which are the most energy-intensive sectors. 


\section{Sensitivity analysis}

In this section we evaluate the sensitivity of the results under the income tax recycling case for a range of parameter values reported in Table 2. Given that we introduce a tax on industrial consumption of fuels the results obtained so far can be sensitive to the values of the elasticities of substitution in the nested production structure as represented in Figure 1 and 2. In the first column of Table 2, we report the default values used in the analysis so far. In the second column we increase the elasticity of all renewable sectors while in the third column the only elasticity we change is that between electricity and non-electricity. The simulations results obtained using these parameter values are reported in Figure 8 and 9 and for the case in which revenues are recycled through reduction in the labour income tax rate.

In Scenario B for all rates of tax the reduction in $\mathrm{CO} 2$ emissions is lower than Scenario A and $\mathrm{C}$ as depicted in Figure 8. This is the result of a greater economic impact that occurs in this Scenario as shown in Figure 9. Both curves related to scenario B in Figure 8 and 9 are steeper than the other two cases. When the elasticity of substitution between electricity and non-electricity falls, the shift away from fossil fuels is reduced, limiting the negative adverse impact of an increase in taxation and so increasing the second dividend.

For the case where we increase the elasticity of substitution among renewable sectors the reduction in emissions is greater for each simulated tax compare to the other two cases. Making the demand for renewable energy more elastic certainly increases the share of electricity generated by renewables, 
however, it lowers the magnitude of the second dividend as we can see by the relationship between reduced $\mathrm{CO} 2$ and GDP shown in Figure 9.

\section{Conclusions}

There is no doubt about the level of ambition of the Scottish Government's emissions targets, but there must be some doubt about whether it has sufficient policy instruments under its direct control to induce households and firms to behave in a way that ensures these targets are met. Yet this is the challenge that the Scottish Government faces in the context of liberalized energy markets. While credibility is enhanced by enshrining emissions targets in a legal framework, this is generally insufficient to ensure their satisfaction (McGregor et al, 2012).

The debate on constitutional change continues to gain momentum in the run up to the referendum on independence, scheduled for late 2014. However, regardless of the outcome, the Scottish Government is destined to benefit from a significant enhancement in the extent of its fiscal powers. Against this background, it seems natural to consider the possibility of a Scottish-specific carbon tax. It seems natural because this could be a genuine option under both devo- max and independence. Such a tax is focused on the "bad" of emissions directly and, if implemented in a fiscally neutral way, offers the potential of a double dividend if the revenues are used to subsidise, or reduce the level of existing taxes on, the "good" of employment. Our simulations demonstrate that a carbon tax could simultaneously stimulate employment while reducing emissions and secure a double dividend. 
In our analysis we have shown that the imposition of a carbon tax generates adverse supply effects due to increase in prices when the revenue collected is recycled outwith the region. (In this case, the Scottish Government does not have control revenues and cannot recycle the revenue generated by the tax within the Scottish economy.) The negative economic effects on economic activity and employment are exacerbated by a fall in competitiveness so that demand for Scottish goods and services also fall. This also produces corresponding negative indirect effects on investment and household consumption. However, when the total tax revenue is recycled internally some offsetting effects occur. We consider two possible uses of the enhanced revenues: to stimulate an increase in current government expenditure, or to reduce the rate of income tax. In both cases the total tax-take is the same and it corresponds, in our base year, to $£ 1662$ million at 2000 prices. With revenue recycled through public expenditure, the positive expenditure stimulus is not able fully to offset the negative supply side effects of the increase in energy taxation. For the case in which the revenue is recycled through income tax there is a net positive impact on the economy.

We plan more extensive systematic analysis of the factors that govern both the direction and the scale of the Scottish economy's response to a carbon tax. In particular, we shall investigate the impact of a Scottish carbon tax in circumstances where there are the supply-side effects of public expenditure. Furthermore, the likely impact on the Scottish economy and emissions of climate change policies pursued in the rest-of-the UK, the rest of the EU and the rest of the World is also potentially crucial (Adams and Parmenter, 2013).

We conclude by noting that the estimates that we present here are by no means an upper bound for the potential beneficial impacts of a carbon tax: in the longer term, we would expect the tax to 
stimulate innovation in low-carbon technologies, a positive effect that is absent from our current analysis. Furthermore, in current circumstances, it may be thought desirable to seek to focus the beneficial impacts more carefully, for example by recycling revenues to subsidise employment among the younger age groups who have been most adversely impacted by the recession and its aftermath. The results that we report here are sufficiently promising to merit more extensive analysis of the likely economic and environmental impacts of a Scottish carbon tax. 


\section{References}

Adams, P.D. and B.R. Parmenter, 2013. Computable General Equilibrium Modelling of Environmental Issues in Australia: Economic Impacts of an Emissions Trading Scheme. Handbook of Computable General Equilibrium Modeling (Edited by Peter B. Dixon and Dale W. Jorgenson) SET, Vols. 1A and 1B

Allan, G., McDonald, J., McGregor, P., Swales, K.J., 2008. A distinctive energy policy for Scotland. Fraser of Allander Economic Commentary, Vol. 32 (1), pp. 46-61.

Armington, P., 1969. A theory of demand for products distinguished by place of production. IMF Staff Papers, 16, 157-178.

Blanchflower, G.D., Oswald, A.J., 1984. Estimating a Wage Curve for Britain. The Economic Journal, Vol. 104, No. 426, pp. 1025-43

Bor, Y.J., Huang, Y., 2010. Energy taxation and the double dividend effect in Taiwan's energy conservation policy: an empirical study using a computable general equilibrium model. Energy Policy, vol. 38(5), pages 2086-2100.

Bosquet, 2000. Environmental tax reform: does it work? A survey of the empirical evidence. Ecological Economics, vol 34, pp. 19-32.

Bovenberg, L. A., Goulder, L. H., 1996. Optimal Environmental Taxation in the Presence of Other Taxes: General-Equilibrium Analyses. American Economic Review, 86(4): 985-1000.

Bovenberg, L. A., Van der Ploeg, F., 1998. Consequences of Environmental Tax Reform for Unemployment and Welfare. Environmental \& Resource Economics, European Association of Environmental and Resource Economists, vol. 12(2), pages 137-150,

Coase, R., 1960. The Problem of Social Cost. Journal of Law and Economics, vol. 3, pp. 1-44.

Cornwall, A., Creedy, J., 1996. Carbon taxation, prices and inequality in Australia. Fiscal Studies, 17(3), 39-61.

Evans, D.J., 2005. The Elasticity of Marginal Utility of Consumption: Estimates for 20 OECD Countries. Fiscal Studies, Vol. 26, No. 2, pp. 197-224.

Fulloerton, D., Metcalf, G., 1998. Environmental Taxes and the Double-Dividend Hypothesis: Did You Really Expect Something for Nothing? Chicago-Kent Law Review, vol.73, pp. 221-256.

Gibson, H., 1990. Export Competitiveness and UK Sales of ScottishManufacturers. Working Paper, Scottish Enterprise, Glasgow 
Glomm, G., Kawaguchi, D., Sepulveda, F., 2008. Green taxes and double dividends in a dynamic economy. Journal of Policy Modeling, Elsevier, vol. 30(1), pages 19-32.

Goulder, L. H., 1995. Effects of Carbon Taxes in an Economy with Prior Tax Distortions: An Intertemporal General Equilibrium Analysis. Journal of Environmental Economics and Management, 29: 271-297.

Goulder, L.H., Mathai, K., 2000. Optimal CO2 Abatement in the Presence of Induced Technological Change. Journal of Environmental Economics and Management, Vol. 39, pp.1-38.

Goulder, L.H., Schneider, S.H., 1999. Induced Technological Change and the Attractiveness of CO2 Abatement Policies. Resource and Energy Economics, Vol. 21, pp. 211-53.

Harris, R.I.D., 1989. The Growth and Structure of the UK Regional Economy, 1963-85, Avebury, Aldershot.

Hayashi F., 1982. Tobin's Marginal q and Average q: A neoclassical Interpretation. Econometrica, Vo. 50, No.1, pp. 213-224.

Lecca P., McGregor P.G., Swales, K.J., 2012. Balanced Budget Government Spending in a Small Open Regional Economy. ERSA conference papers ersa12p1009, European Regional Science Association.

Lecca, P., McGregor, P. G. and Swales, J. K. (2013) Forward-looking versus myopic regional computable general equilibrium models: how significant is the distinction? Economic Modelling, vol. 3, no. 6, pp 160-176.

Lecca, P., McGregor, P.G., Swales, J. K., Yin, Y. P., (2014) Balanced budget fiscal expansions in small open regions within a federal system: evidence from the Scottish variable rate of income tax, forthcoming, Journal of Regional Science. (Revised version of Inverted Haavelmo Effects in a General Equilibrium Analysis of the Impact of Implementing the Scottish Variable Rate of Income Tax. SIRE Discussion Papers 2010-47, Scottish Institute for Research in Economics (SIRE)).

Hoel M., Schneider K., 1997. Incentives to participate in an international environmental agreement. Environmental \& Resource Economics, European Association of Environmental and Resource Economists, vol. 9(2), pages 153-170, March.

Jorgenson D.W., (1963). Capital Theory and Investment Behaviour. American Economic Review, Vol. 53, No. 2, pp. 247-259.

Layard R., Nickell S., Jackman R., 1991. Unemployment: Macroeconomic Performance and the Labour Market. Oxford University Press, Oxford.

Manresa, A., Ferran, S., 2005. Implementing a double dividend: recycling ecotaxes towards lower labour taxes. Energy Policy, Elsevier, vol. 33(12), pages 1577-1585, August. 
McGregor, P.G., Swales, J.K. and Winning, M., 2012. A review of the role and remit of the committee on climate change. Energy Policy, Elsevier, vol. 41(C), pp. 466-473.

McGregor, P. G. and Swales, J. K. 2013 "The Impact of Greater Autonomy on Scottish Climate Change Policy", Chapter 7 in A. Goudie (ed.) Scotland's Future: The Economics of Constitutional Change (Dundee University Press: Dundee).

Nordhaus, W., 2012. Why the global warming sceptics are wrong. The New York Review of Books, vol. 59 , no. 5, pp. 32-34.

Pant, H., 2007. GTEM: Global Trade and Environment Model. Australian Bureau of Agricultural and Resource Economics, Canberra

Pearce, D., 1991. The role of carbon taxes in adjusting to global warming. Economic Journal, vol. 101, pp. 938-948.

Pigou, A.C., 1920. The Economics of Welfare, Macmillan, London.

Symons, E., Proops, J., Gay, P., 1994. Carbon taxes, consumer demand and carbon dioxide emissions: a simulation analysis for the UK. Fiscal Studies, 15(2), 19-43.

Tullock, G., 1967. Excess benefit. Water Resources Research, vol. 3, pp. 643-644.

Uzawa H., 1969. The Preference and Penrose Effect in a Two-Class Model of Economic Growth". The Journal of Political Economy, Vol. 77, No.4, pp. 628-652.

Turner, K., 2002. PhD Dissertation. University of Strathclyde.

Jan van Heerden, Gerlagh R., Blignaut, J., Horridge, M., Hess S., Mabugu R., Mabugu, M., 2006. Searching for Triple Dividends in South Africa: Fighting CO2 Pollution and Poverty while Promoting Growth. The Energy Journal, vol. 0(Number 2), pages 113-142.

Weitzman, M., 1974. Prices vs Quantities. Review of Economic Studies, vol. 41, pp. 477-491.

Wissema, W., Dellink, R., 2007. AGE analysis of the impact of a carbon energy tax on the Irish economy. Ecological Economics, Elsevier, vol. 61(4), pages 671-683. 
Table 1. Impact of implementing a $£ 50$ per tonne carbon tax in Scotland on key macrovariables: Percentage change from base year values

\begin{tabular}{|c|c|c|c|c|c|c|}
\hline & \multicolumn{2}{|c|}{ Externally Recycled } & \multicolumn{2}{|c|}{$\begin{array}{l}\text { Internally Recycled } \\
\text { Public Expenditure }\end{array}$} & \multicolumn{2}{|c|}{$\begin{array}{c}\text { Internally Recycled } \\
\text { Income Tax }\end{array}$} \\
\hline & Short-run & Long-run & Short-run & Long-run & Short-run & Long-run \\
\hline $\mathrm{CO} 2$ Emissions & -32.66 & -39.34 & -32.55 & -38.84 & -31.83 & -37.49 \\
\hline GDP & -0.30 & -2.68 & -0.14 & -1.37 & 0.26 & 0.83 \\
\hline Unemployment Rate & 4.08 & 0.00 & 1.79 & 0.00 & -3.77 & 0.00 \\
\hline Total Employment & -0.45 & -2.60 & -0.20 & -1.27 & 0.42 & 1.06 \\
\hline Nominal Gross Wage & -0.60 & 0.81 & 0.24 & 0.81 & -0.88 & -1.43 \\
\hline Real Wage After Tax & -0.45 & 0.00 & -0.20 & 0.00 & 0.43 & 0.00 \\
\hline Replacement Cost of Capital & -0.26 & 0.63 & 0.50 & 0.63 & 0.07 & -0.36 \\
\hline Labour Supply & 0.00 & -2.60 & 0.00 & -1.27 & 0.00 & 1.06 \\
\hline Household Consumption & -0.90 & -1.68 & -0.56 & -0.87 & 1.18 & 1.45 \\
\hline Govt. Consumption & - & - & 4.66 & 3.97 & - & \\
\hline Income Tax Rate & - & - & - & & -6.16 & -5.37 \\
\hline Capital Stock & 0.00 & -2.82 & 0.00 & -1.53 & 0.00 & 0.40 \\
\hline Export & 0.14 & -1.23 & -0.55 & -1.23 & -0.29 & 0.05 \\
\hline
\end{tabular}


Table 2

Parameter Values

\begin{tabular}{|l|r|r|r|}
\hline Elasticities & \multicolumn{1}{|c|}{ Default } & \multicolumn{1}{|c|}{ B } & \multicolumn{1}{|c|}{ C } \\
\hline Intermediate-Value Added & 0.3 & 0.3 & 0.3 \\
\hline Energy and non-energy & 0.3 & 0.3 & 0.3 \\
\hline Electricity and non-electricity & 2 & 2 & 0.3 \\
\hline Oil and non-oil & 2 & 2 & 2 \\
\hline Transmission and generation & 0.3 & 0.3 & 0.3 \\
\hline Intermittent and non-intermittent & 5 & 10 & 5 \\
\hline Between non-intermittent & 5 & 10 & 5 \\
\hline Wind and marine & 5 & 10 & 5 \\
\hline On and off shore wind & 5 & 10 & 5 \\
\hline Between non-energy & 0.3 & 0.3 & 0.3 \\
\hline
\end{tabular}


Figure 1. Production structure - Electricity sector-

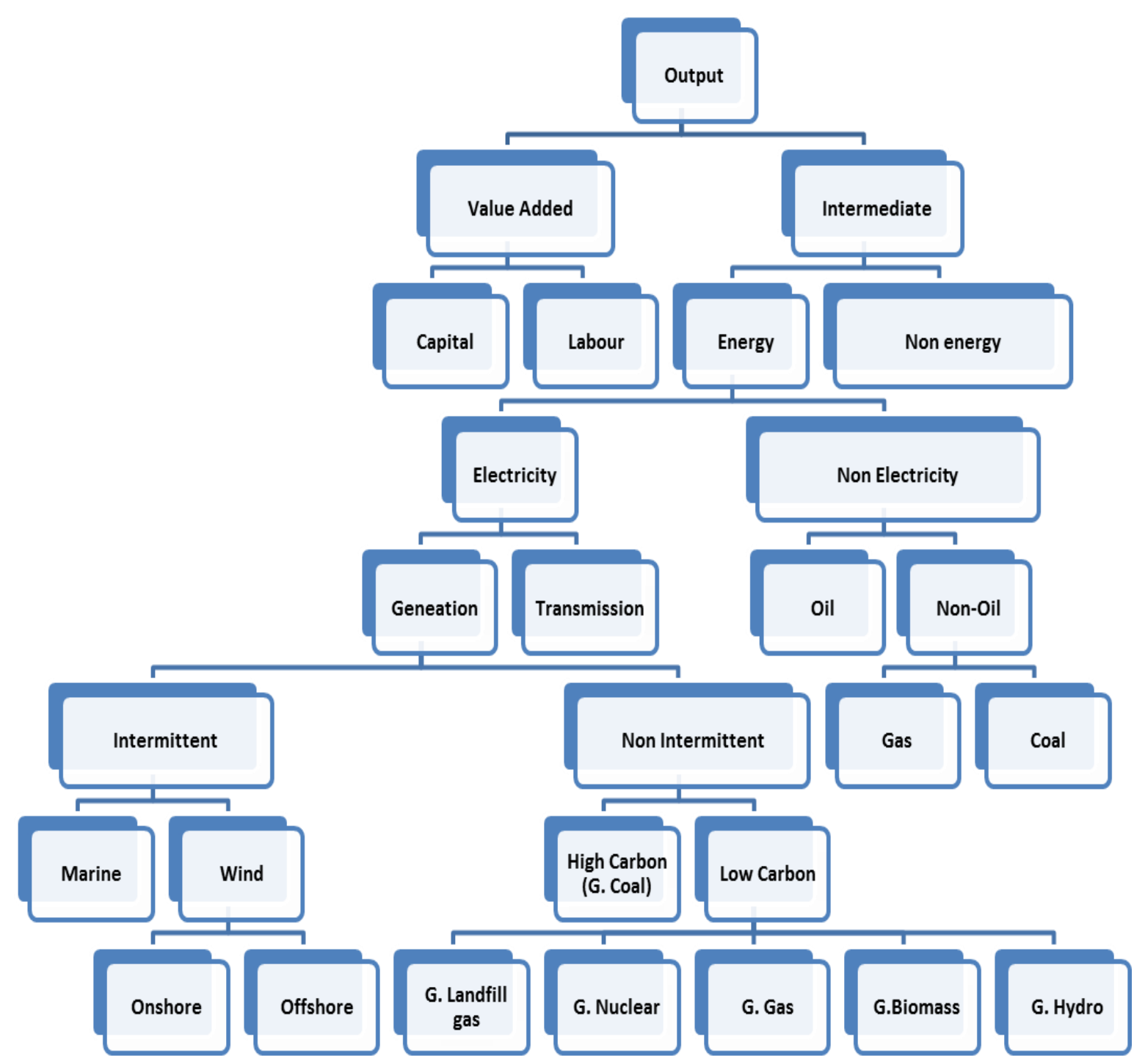


Figure 2. Production structure for all the other sectors

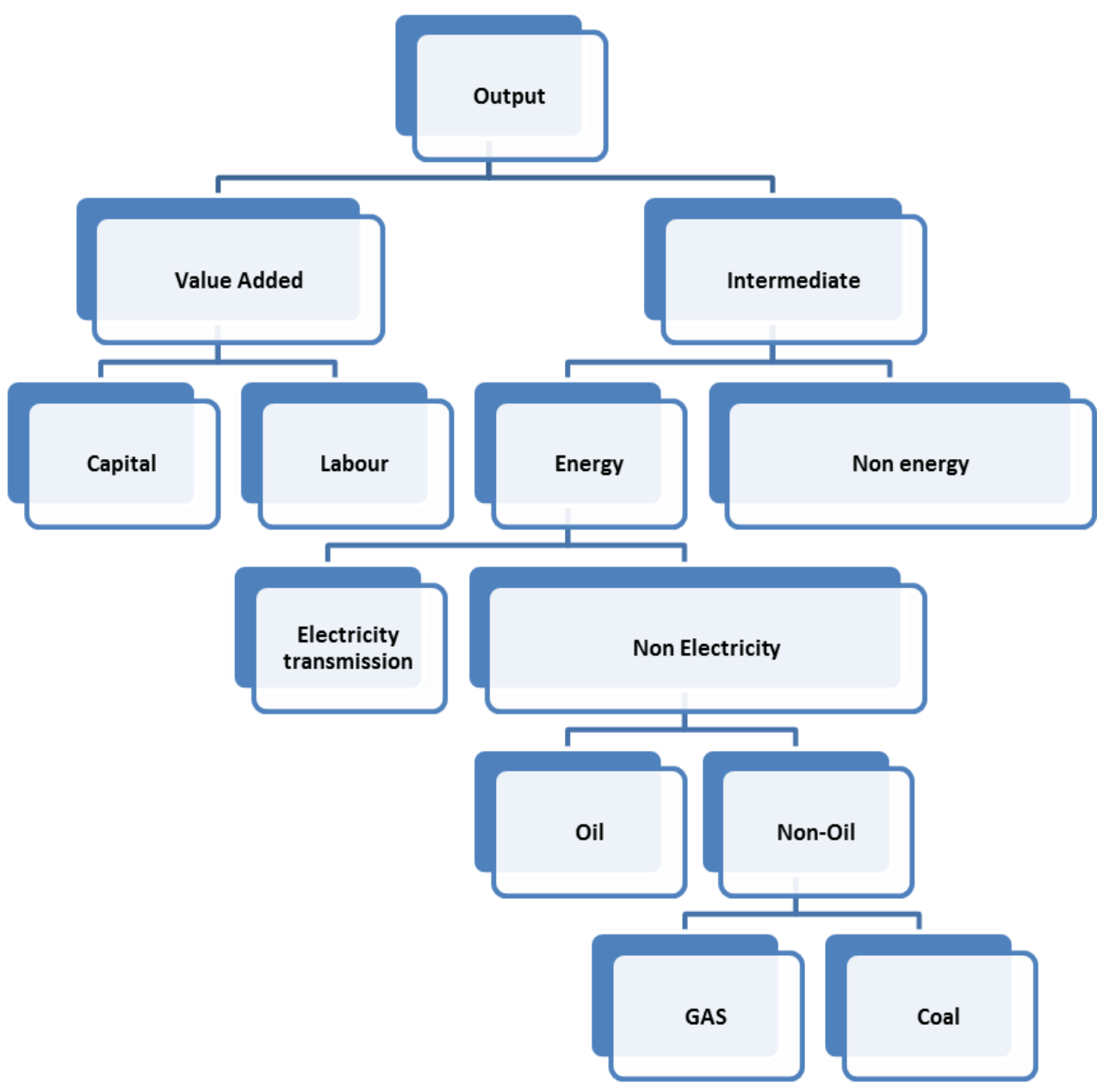


Figure 3. Reduction of $\mathrm{CO} 2$ emissions for a range of possible tax rate under three recycling methods

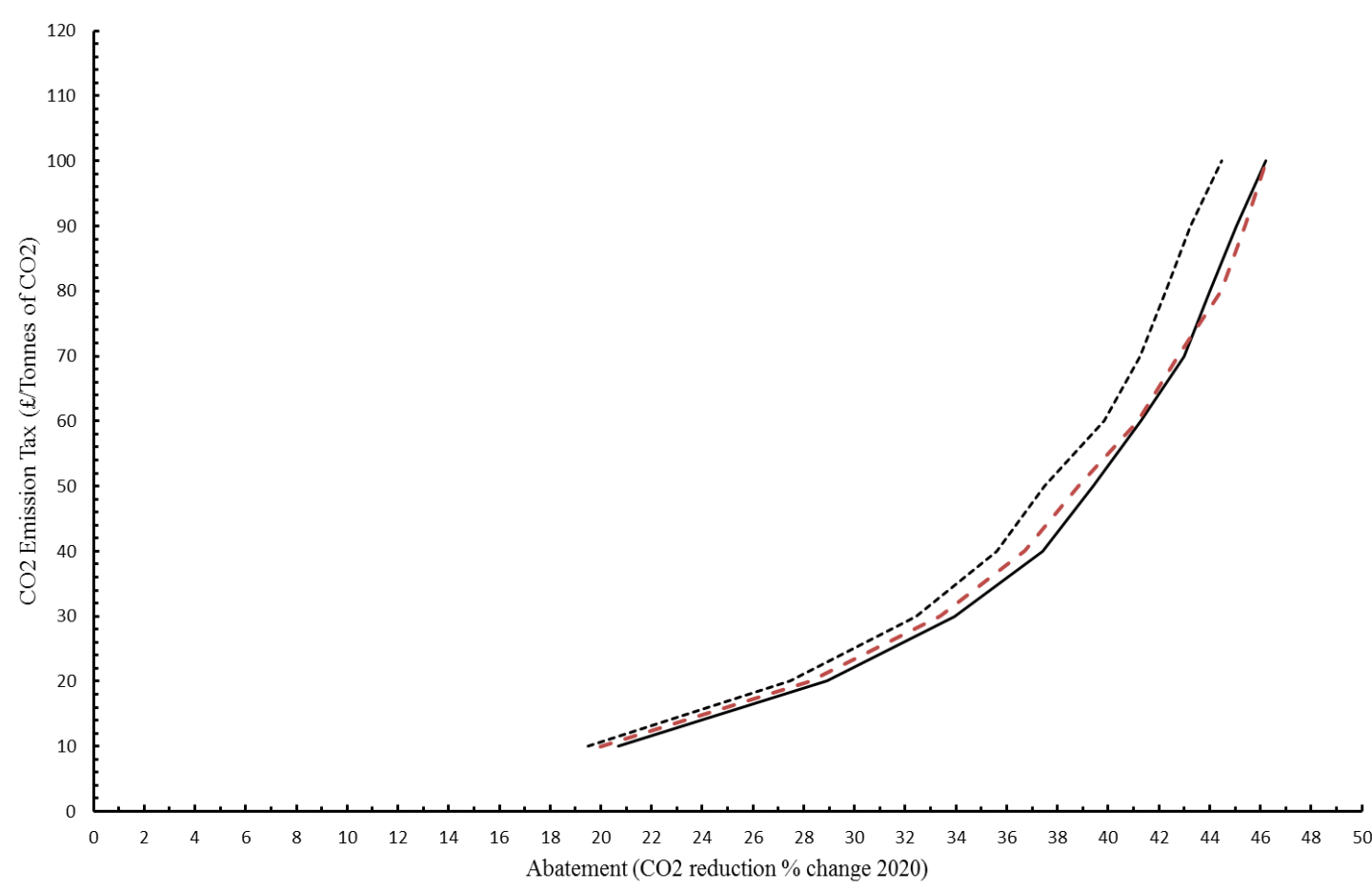

—External recycle - - Internal Recycle (Govt. Exp.) -----Internal recycle (Income tax) 
Figure 4. The short and long-run percentage change in sectoral output for a $£ 50$ per tonne tax on $\mathrm{CO}_{2}$ emissions with revenue recycling through a reduction in income tax

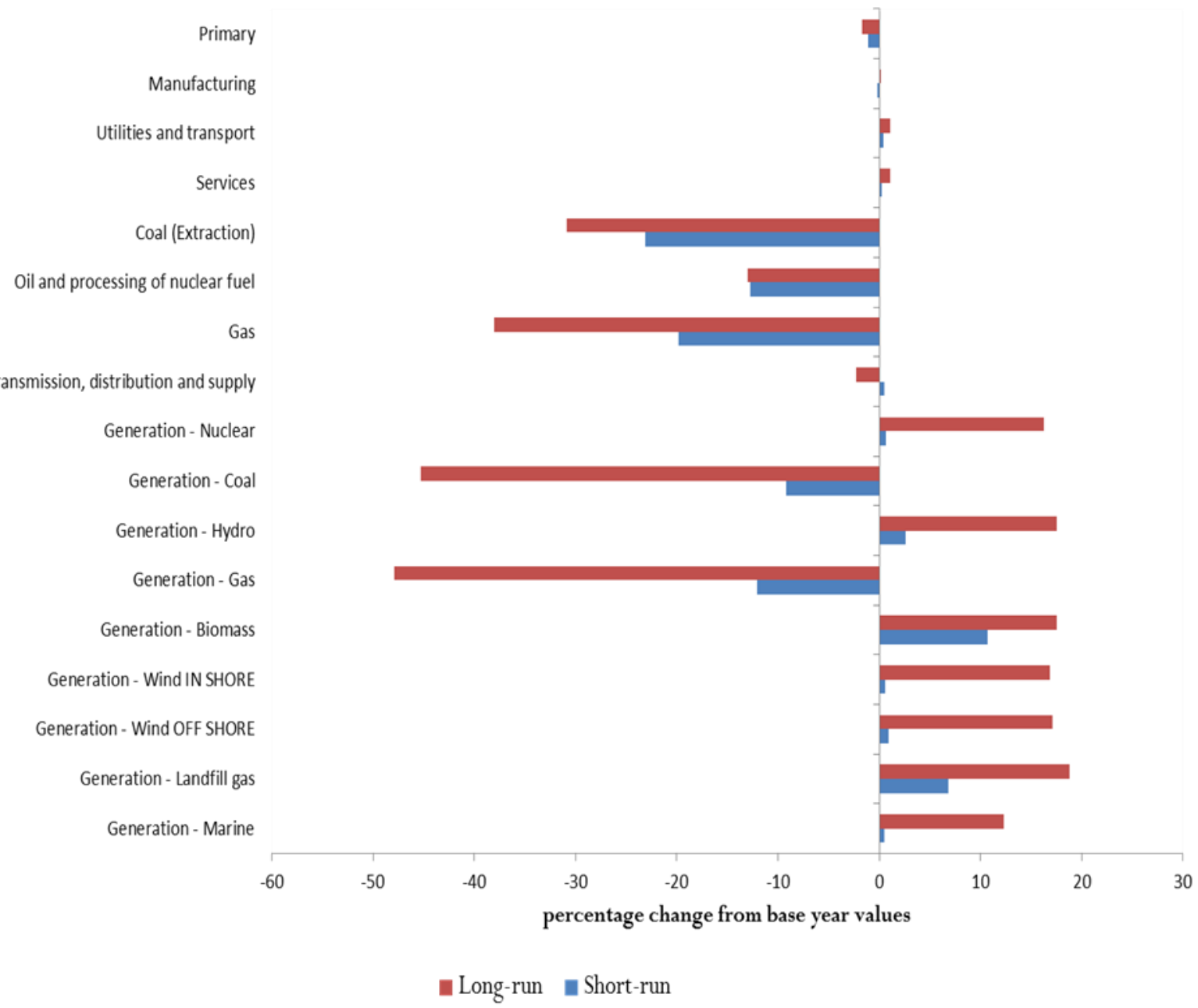


Figure 5. Change in total $\mathrm{CO} 2$ emissions for a $£ 50$ per tonne tax on carbon emissions for all three forms of revenue recycling

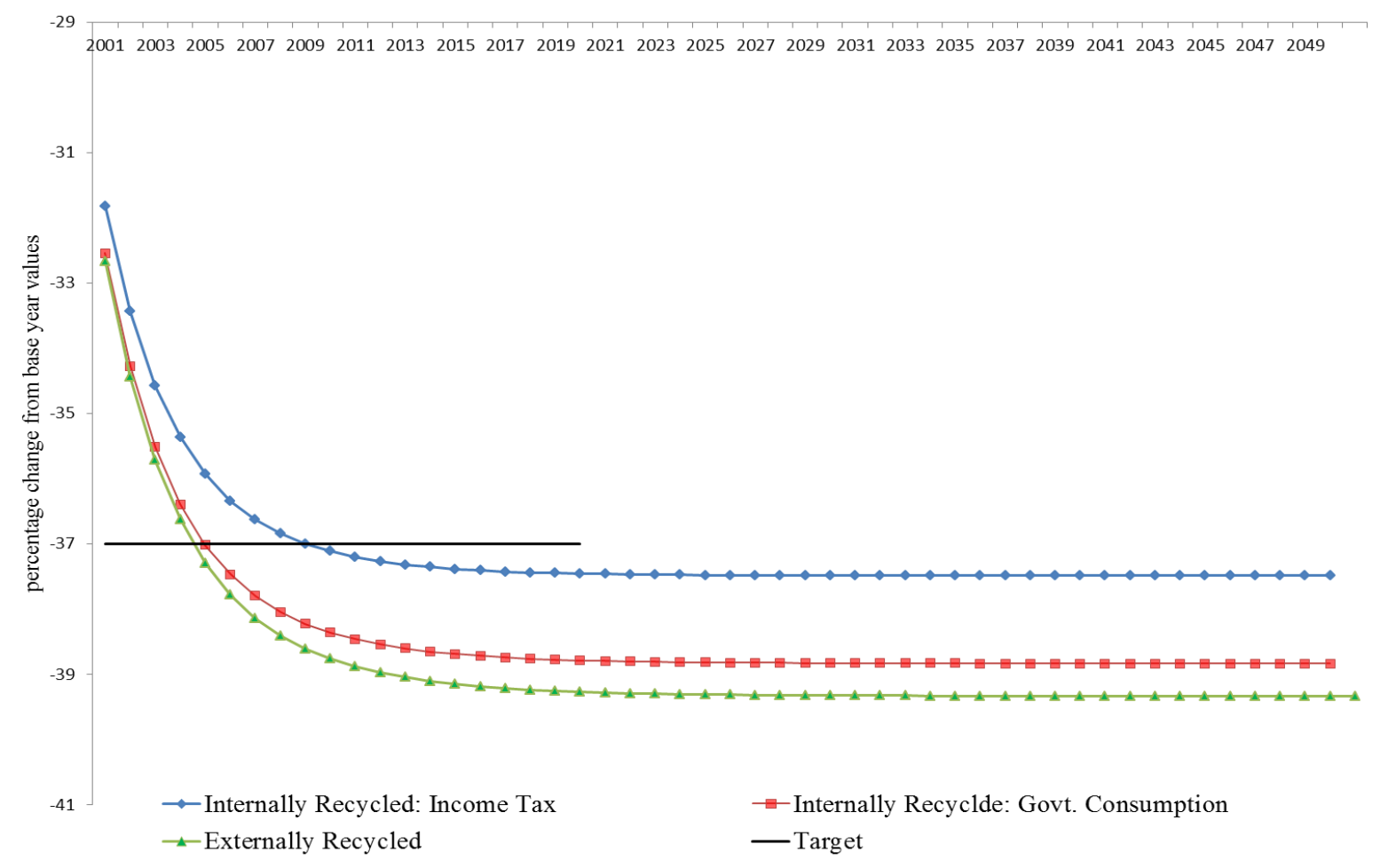


Figure 6. \% reduction in total $\mathrm{CO}_{2}$ emissions for a $£ 50$ per tonne tax with revenue recycling through a reduction in income tax. A comparison between myopic and perfect foresight agents

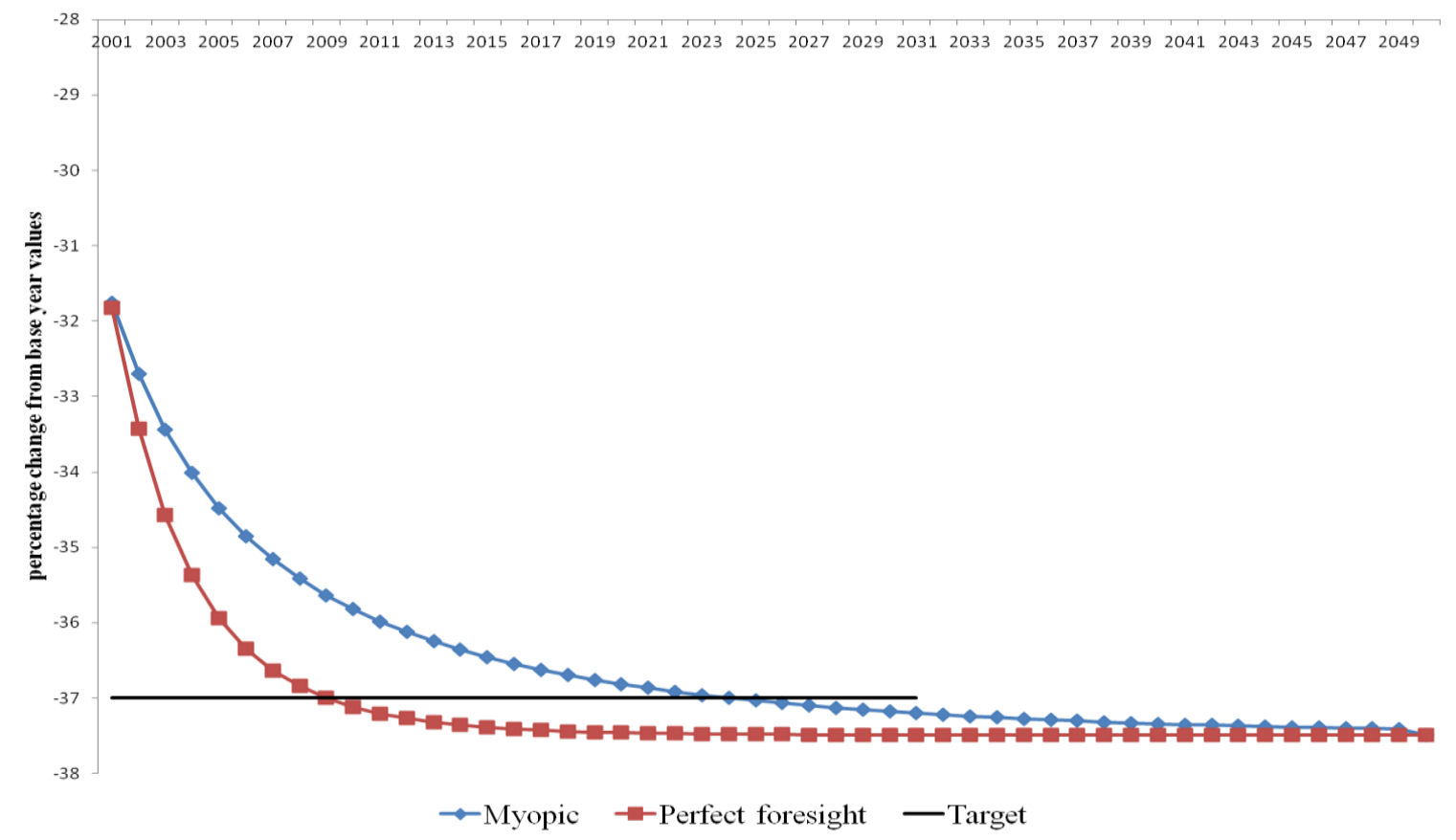


Figure 7: The short and long-run \% reductions in sectoral $\mathrm{CO}_{2}$ emissions for a $£ 50$ tonne tax with revenue recycling through a reduction in income tax.

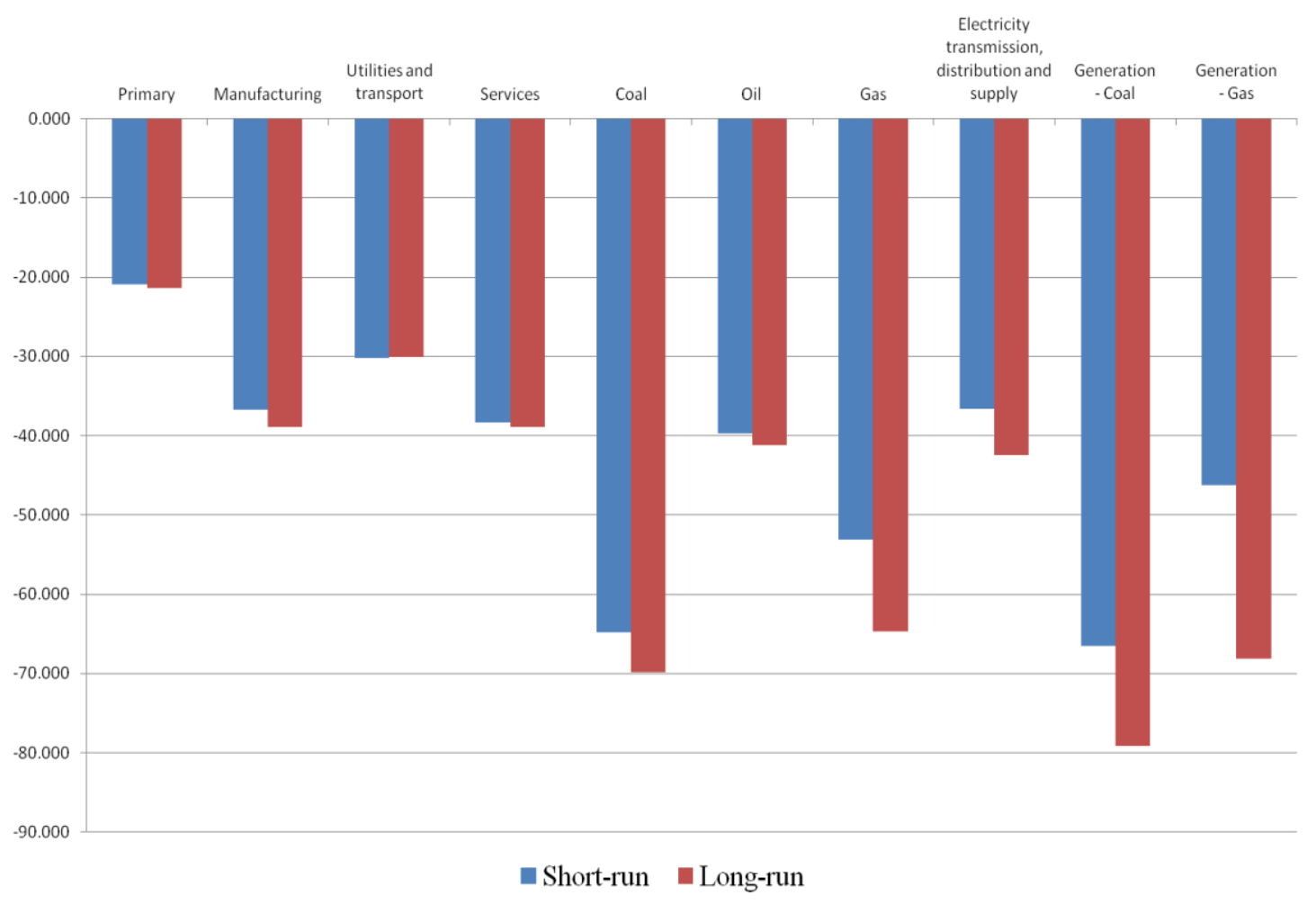


Figure 8. Reduction of $\mathrm{CO} 2$ emissions for a range of possible tax rate under different parameter values

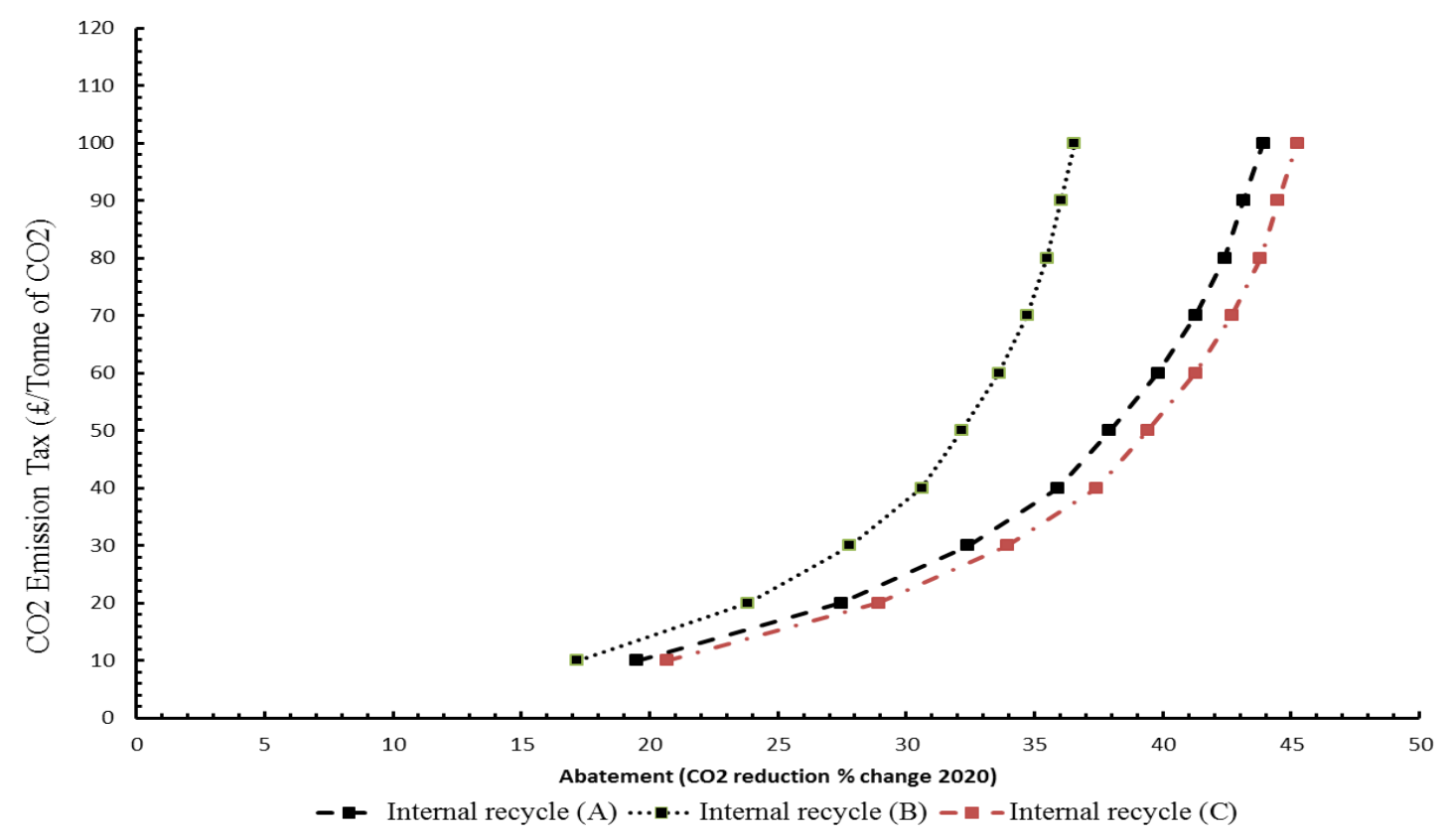

Figure 9. Change in GDP and Emissions under different parameterizations

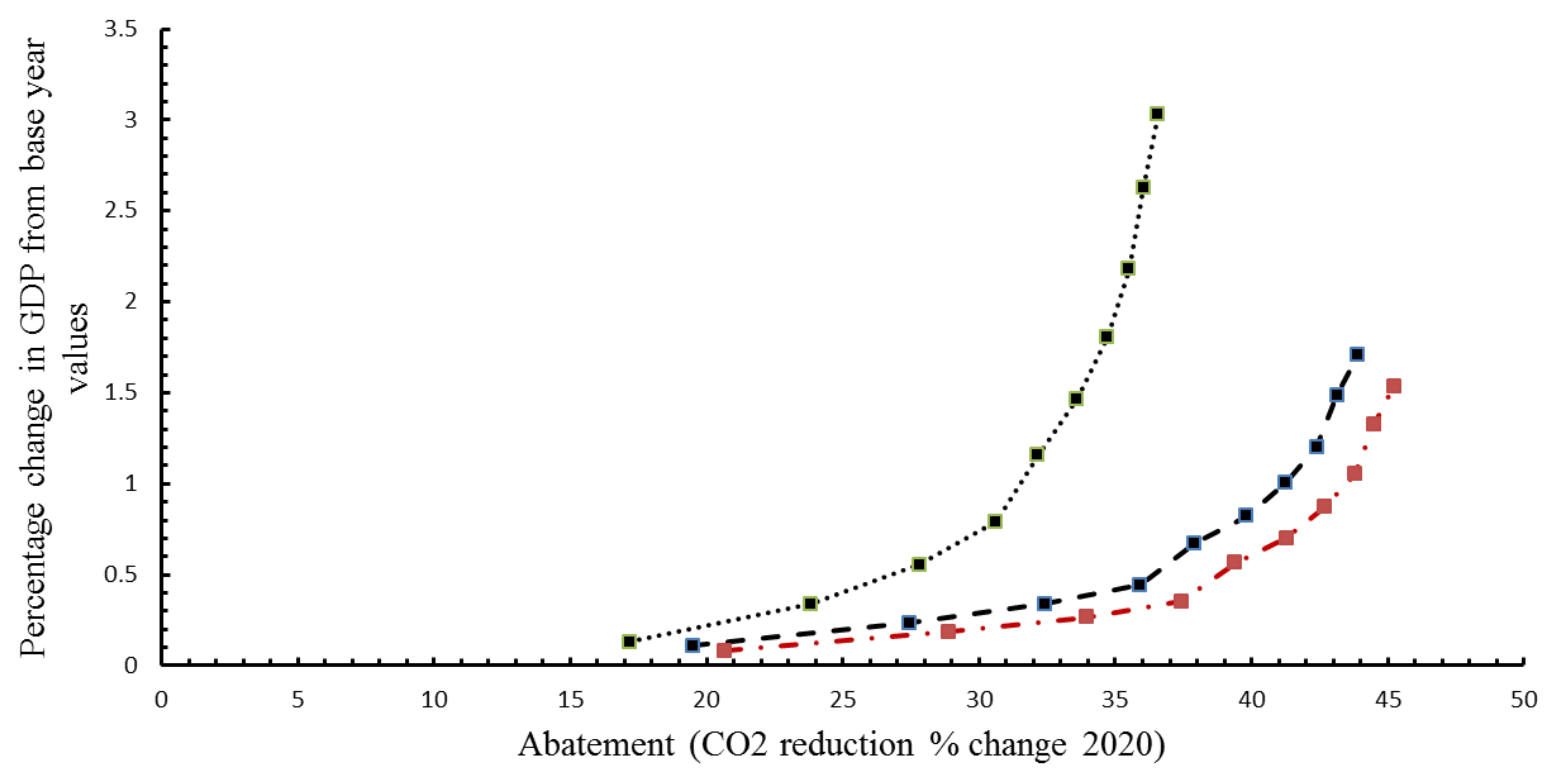

- - Internal Recycle (A) …*. Internal recycle (B) - - - - Internal Recycle (C) 
Table A1

\section{Sectoral Breakdown}

\begin{tabular}{|l|c|}
\hline & $\begin{array}{l}\text { Original } \\
\text { Sector } \\
\text { Number } \\
\text { Included } \\
\text { from 123 UK } \\
\text { IO }\end{array}$ \\
\hline Aggregated IO Sector & 1 -3+5-7 \\
\hline Primary & $8-34+36-84$ \\
\hline Utilities and transport 87+88 93-97 & $87-88+93-97$ \\
\hline Services & $89-92+98-123$ \\
\hline Coal (Extraction) & 4 \\
\hline $\begin{array}{l}\text { Oil (refining and treatment of oil and } \\
\text { petroleum products) and processing of } \\
\text { nuclear fuel }\end{array}$ & 35 \\
\hline Gas & 86 \\
\hline $\begin{array}{l}\text { Electricity transmission, distribution and } \\
\text { supply }\end{array}$ & 85 \\
\hline Generation - Nuclear & 85 \\
\hline Generation - Coal & 85 \\
\hline Generation - Hydro & 85 \\
\hline Generation - Gas & 85 \\
\hline Generation - Biomass & 85 \\
\hline Generation - Wind IN SHORE & 85 \\
\hline Generation - Wind OFF SHORE & 85 \\
\hline Generation - Landfill gas & 85 \\
\hline Generation - Marine & \\
\hline
\end{tabular}


Table A2

Sectoral $\mathrm{CO}_{2}$ emissions linked to output and fuels use, 2000 (thousands tonnes of oil equivalent)

\begin{tabular}{|l|r|r|r|r|r|}
\hline & \multicolumn{1}{|c|}{ Output } & \multicolumn{1}{c|}{ Coal } & \multicolumn{1}{c|}{ Oil } & \multicolumn{1}{c|}{ Gas } & \multicolumn{1}{c|}{ Total } \\
\cline { 2 - 5 } Primary & 429.00 & 57.26 & 955.75 & 20.74 & 1462.76 \\
Manufacturing & 508.00 & 963.99 & 2020.09 & 2393.87 & 5885.95 \\
Utilities and transport & 0.00 & 143.58 & 5238.47 & 757.44 & 6139.50 \\
Services & 0.00 & 440.34 & 2168.18 & 837.89 & 3446.40 \\
Coal (Extraction) & 0.00 & 189.03 & 71.62 & 1.29 & 261.93 \\
Oil & 322.00 & 477.41 & 797.00 & 57.94 & 1654.35 \\
Gas & 0.00 & 0.00 & 1.83 & 3326.05 & 3327.88 \\
Electricity transmission, distribution & & & & & \\
and supply & 0.00 & 0.00 & 221.65 & 588.33 & 809.98 \\
Generation - Nuclear & 0.00 & 0.00 & 0.00 & 0.00 & 0.00 \\
Generation - Coal & 0.00 & 8262.26 & 0.00 & 307.12 & 8569.38 \\
Generation - Hydro & 0.00 & 0.00 & 0.00 & 0.00 & 0.00 \\
Generation - Gas & 0.00 & 0.00 & 4.37 & 2950.49 & 2954.86 \\
Generation - Biomass & 0.00 & 0.00 & 0.00 & 0.00 & 0.00 \\
Generation - Wind IN SHORE & 0.00 & 0.00 & 0.00 & 0.00 & 0.00 \\
Generation - Wind OFF SHORE & 0.00 & 0.00 & 0.00 & 0.00 & 0.00 \\
Generation - Landfill gas & 0.00 & 0.00 & 0.00 & 0.00 & 0.00 \\
Generation - Marine & 0.00 & 0.00 & 0.00 & 0.00 & 0.00 \\
\hline Total sectoral emissions & 1259.00 & 10533.87 & 11478.96 & 11241.16 & 34512.99 \\
Final demand & -184.60 & 8062.70 & 5749.37 & 13996.67 \\
\hline Total emissions & 1259.00 & 10718.47 & 19541.66 & 16990.53 & 48509.65 \\
\hline
\end{tabular}


